\title{
Experimental Investigation of Concrete with Glass Powder as Partial Replacement of Cement
}

\author{
S. Rahman*, M.N. Uddin \\ Department of Civil Engineering, Port City International University, Chittagong, Bangladesh
}

Copyright $\odot 2018$ by authors, all rights reserved. Authors agree that this article remains permanently open access under the terms of the Creative Commons Attribution License 4.0 International License

\begin{abstract}
The effects of partially replacing of cement with glass powder in concrete were studied and therefore found that some extent could be replaced which contributes in strength development. Cement was partially replaced with glass powder at varying percentages such as $10 \%, 20 \%$ and $30 \%$ and several concrete cylinders were casted along with plain concrete specimen. The cylinders were tested for compressive strength and split tensile strength at the age of 7,14 and 28 days and were compared with the results of plain concrete. The overall test results indicated that the waste glass powder could be utilized in concrete as a good substitute of cement up to particle size less than $75 \mu \mathrm{m}$. In replacement of cement with glass powder of $10 \%$, the compressive strength and split tensile strength were reduced in $7^{\text {th }}$ days for all samples. The $20 \%$ replacement of cement by glass powder met maximum compressive strength as compared to that of plain concrete. At 28 days, $30 \%$ replacement of cement by glass powder met maximum split tensile strength as compared to that of plain concrete.
\end{abstract}

Keywords Concrete, Glass Powder, Compressive Strength, Split Tensile Strength

\section{Introduction}

Concrete is widely popular throughout the construction industry due to the various advantages of accessibility, availability and economy associated with it. It is made by the mixing of binding material, generally cement, fine aggregate and coarse aggregate with water. Cement is the main components of concrete, which works as a binder between coarse aggregate and fine aggregate, with the help of water. It has own environmental impacts and contributes largely to concrete. However, the production of cement leads to the release of significant amount of $\mathrm{CO}_{2}$, a greenhouse gas. Environmental issues are playing an important role in the sustainable development of the cement and concrete industry. The recycling of each ton of glass saves over one ton of natural resources, and recycling of every six tons of container glass results in the reduction of one tone of $\mathrm{CO}_{2}$ emission [1]. Numerous efforts have been made within the concrete industry to use waste glass (WG) as a partial replacement for natural aggregates or ordinary Portland cement (OPC) [2].

Rahman[3] found an inventive logical occurrence. The presence of the Pozzolanic Glass Powder in concrete could also intensify the plastic properties of concrete. Milled waste glass was also found to suppress alkali-silica reactions hence increase durability of concrete. Use of milled waste glass in concrete as partial replacement of cement represents an important step towards development of sustainable concrete-based infrastructure systems.

Milling of glass to micrometer scale particle size, for accelerating the reactions between glass and cement hydrates, can bring major energy, environmental and cost benefits when cement is partially replaced with milled waste glass for production of concrete [3].

\subsection{Chemical Properties of Cement and Glass Powder}

Chemical properties of cement and glass powder are quiet similar, but the percentages are different. Chemical properties of glass powder and cement are given in Table 1 [4].

Table 1. Chemical properties of cement and glass powder

\begin{tabular}{|c|c|c|}
\hline Properties & $\begin{array}{c}\text { Waste glass } \\
\text { powder }\end{array}$ & Cement \\
\hline $\mathrm{SiO}_{2}(\%)$ & 70.22 & 23.71 \\
\hline $\mathrm{CaO}(\%)$ & 11.13 & 57.27 \\
\hline $\mathrm{MgO}(\%)$ & - & 3.85 \\
\hline $\mathrm{Al}_{2} \mathrm{O}_{3}(\%)$ & 1.64 & 4.51 \\
\hline $\mathrm{Fe}_{2} \mathrm{O}_{3}(\%)$ & 0.52 & 4.83 \\
\hline $\mathrm{SO}_{3}(\%)$ & - & 2.73 \\
\hline $\mathrm{Na}_{2} \mathrm{O}(\%)$ & 15.29 & - \\
\hline $\mathrm{K}_{2} \mathrm{O}(\%)$ & - & 0.37 \\
\hline $\mathrm{Cl}(\%)$ & - & 0.0068 \\
\hline Loss on ignition $(\%)$ & 0.80 & 7.24 \\
\hline
\end{tabular}




\section{Materials and Methods}

\subsection{Materials Used}

\subsubsection{Cement}

Ordinary Portland Cement (OPC) was used for casting of concrete. Specific gravity test was done as given in Fig. 1 and the result is given in Table 2 .

Table 2. Test on cement

\begin{tabular}{|c|c|c|}
\hline Name of test & Code Followed & Found value \\
\hline Specific gravity & ASTM C188-16 [5] & 3.13 \\
\hline
\end{tabular}

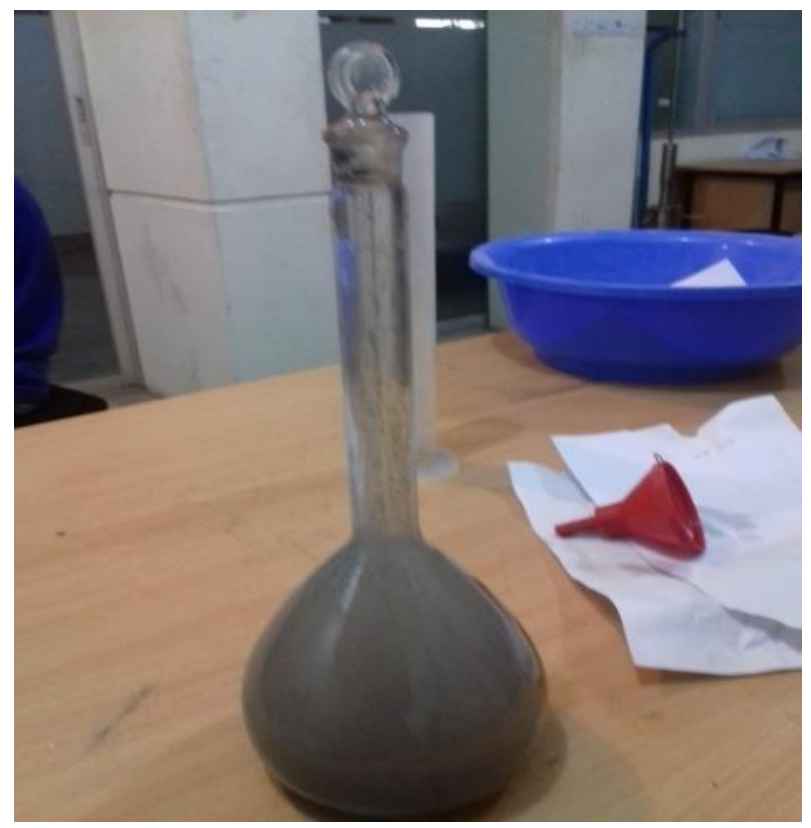

Figure 1. Specific Gravity test of OPC

\subsubsection{Coarse aggregate (CA)}

Stone chips were used to make the plain concrete and glass powder concrete. The size of the aggregate was maintained 1 inch passing, 3/4 inches retained and 3/4 inches passing, $1 / 2$ inches retained. The conducted test results on coarse aggregate are given in the Table 3.

Table 3. Tests on CA

\begin{tabular}{|c|c|c|}
\hline Name of tests & Code followed & Found value \\
\hline Specific gravity & ASTM C127-15 [6] & 2.42 \\
\hline Absorption capacity & ASTM C127-15 & $1.2 \%$ \\
\hline Dry rodded unit & ASTM & $1412.5 \mathrm{~kg} / \mathrm{m}^{3}$ \\
weight & C29-C29M-17 [7] & $\left(102.95 \mathrm{lb} / \mathrm{ft}^{3}\right)$ \\
\hline Gradation & ASTM & Fineness Modulus \\
& C33-C33M-16e1 & 3.1 \\
\hline
\end{tabular}

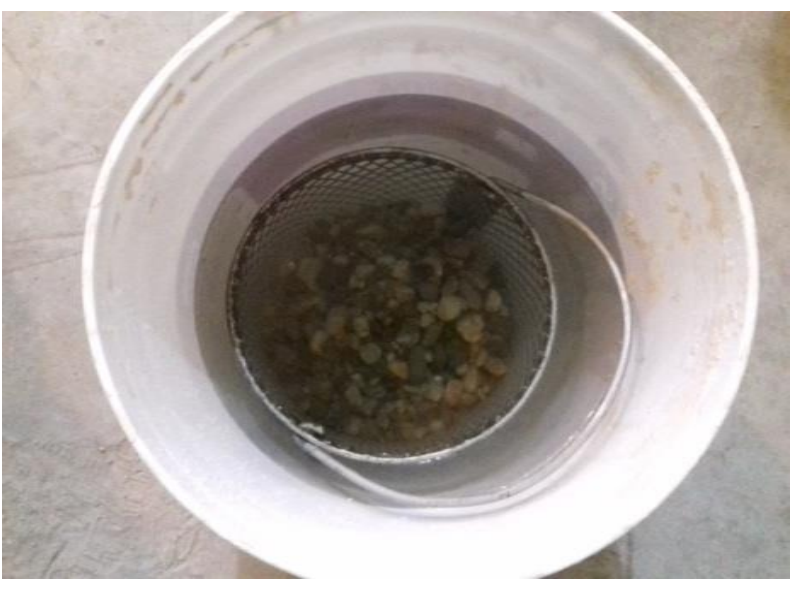

Figure 2. Specific Gravity and Absorption Capacity test of CA

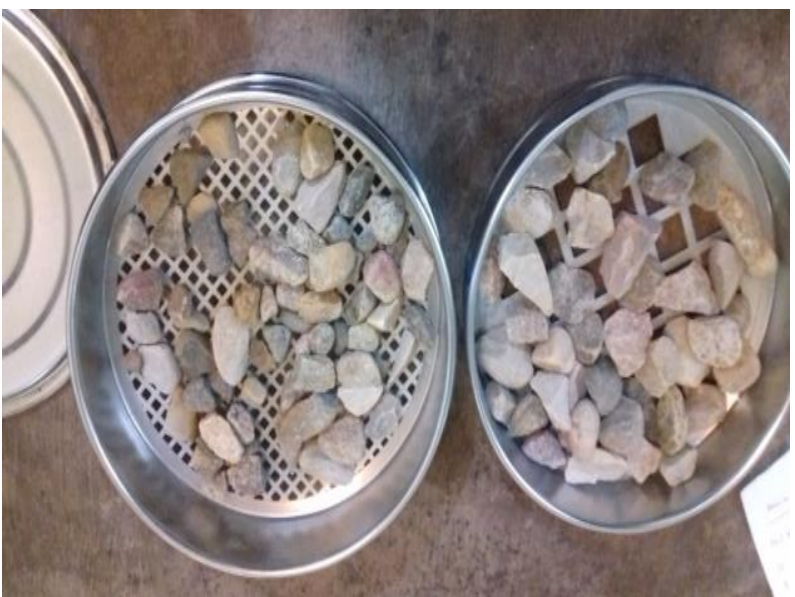

Figure 3. Gradation of CA

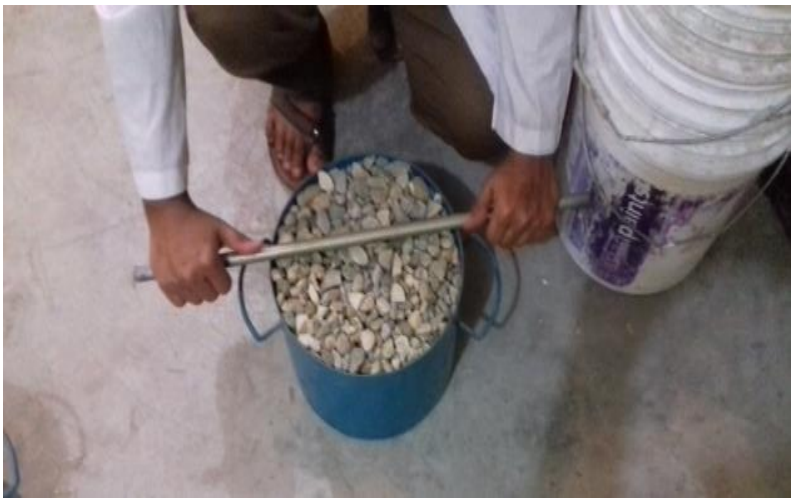

Figure 4. Dry Rodded Unit Weight test of CA

Fig. 2, Fig. 3 and Fig. 4 illustrates the experimental works done for the specfic gravity and absorption capacity, gradation and dry rodded unit weight tests respectively. Again, the gradation curve of corase aggregate is given in Fig. 5. 


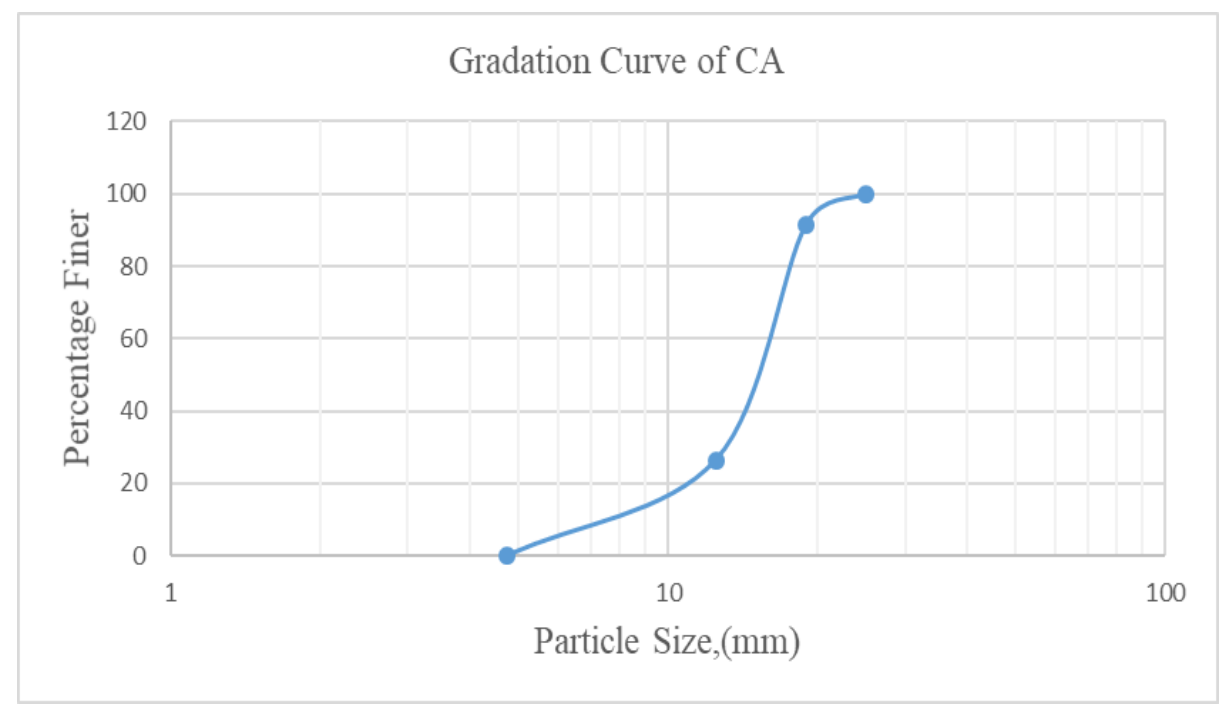

Figure 5. Gradation curve of CA

\subsubsection{Fine Aggregate (FA)}

Sand collected from Sylhet, Bangladesh was used. The conducted test results on fine aggregate are given in the Table 4. Fig. 6 and Fig. 7 are showing the experimental works of specific gravity and absorption capacity and gradation tests of fine aggregates respectively.

Table 4. Tests on FA

\begin{tabular}{|c|c|c|}
\hline Name of tests & Code followed & Found value \\
\hline Specific gravity & ASTM C128-15 [8] & 2 \\
\hline $\begin{array}{c}\text { Absorption } \\
\text { capacity }\end{array}$ & ASTM C128-15 & $21.95 \%$ \\
\hline Gradation & ASTM C778-13 [9] & $\begin{array}{c}\text { Fineness Modulus } \\
2.1\end{array}$ \\
\hline
\end{tabular}

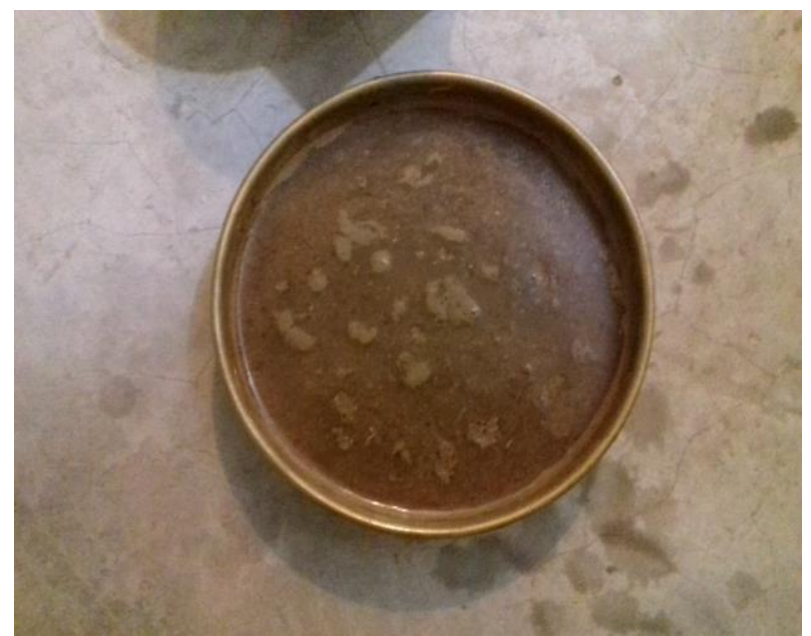

Figure 6. Specific Gravity and Absorption Capacity test of FA

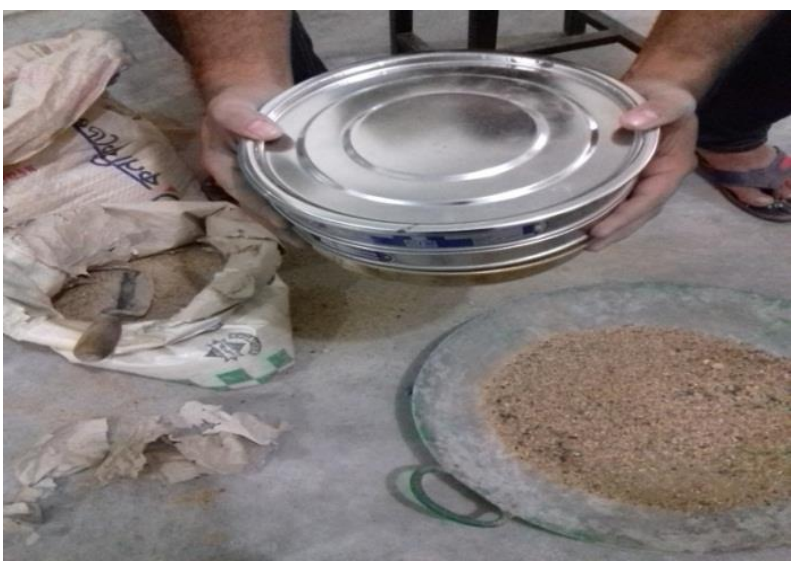

Figure 7. Gradation of FA

\subsubsection{Glass Powder}

Waste glass bottles collected from local source were grinded manually and the size was maintained less than $0.075 \mathrm{~mm}$. The waste glass bottles and the powdered form after grinding are shown in Fig. 8 and Fig. 9 respectively.

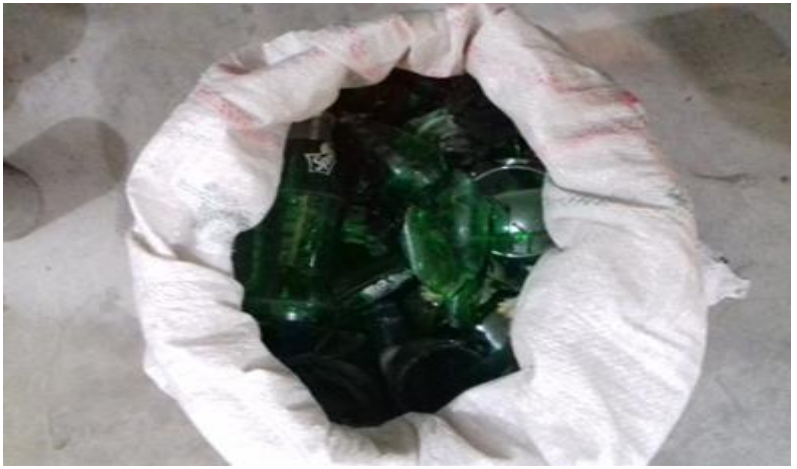

Figure 8. Waste glass bottles 


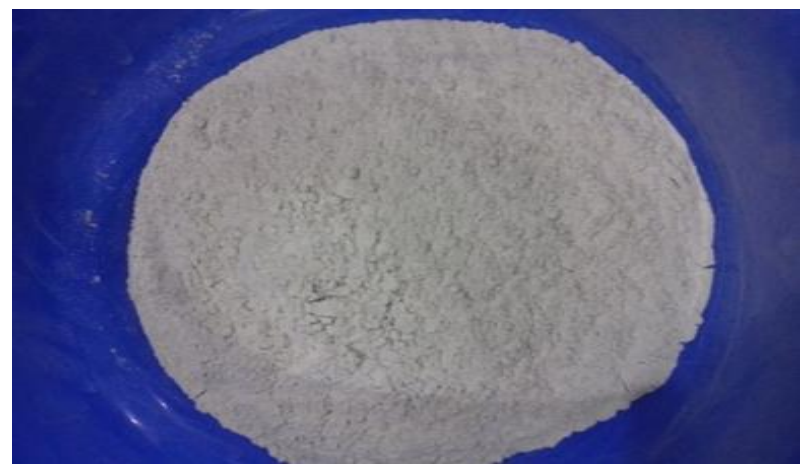

Figure 9. Powdered form of glass

\subsection{ACI Mix Design of Concrete}

From the results of materials tests, ACI mix design was conducted and the ratio among cement (c), fine aggregate (FA) and coarse aggregate (CA) and water-cement ratio (W/C) were found as given in Table 5. The slump value was found as $25 \mathrm{~mm}$.

Table 5. Mix design ratio

\begin{tabular}{|c|c|}
\hline Name & Value \\
\hline C: FA: CA & $1: 2.57: 3.39$ \\
\hline W/C & 0.61 \\
\hline
\end{tabular}

\subsection{Casting and Curing}

Total 24 cylinders were casted as shown in Fig. 10. Among them, 6 cylinders was of cement replaced by $10 \%$ of glass powder, 6 of $20 \%$ and 6 of $30 \%$. In addition, control cylinder was also casted with $0 \%$ glass powder to compare the strength with respect to replacement. After 24 hours of casting, the cylinders were demolded and submerged under water for curing as shown in Fig. 11.

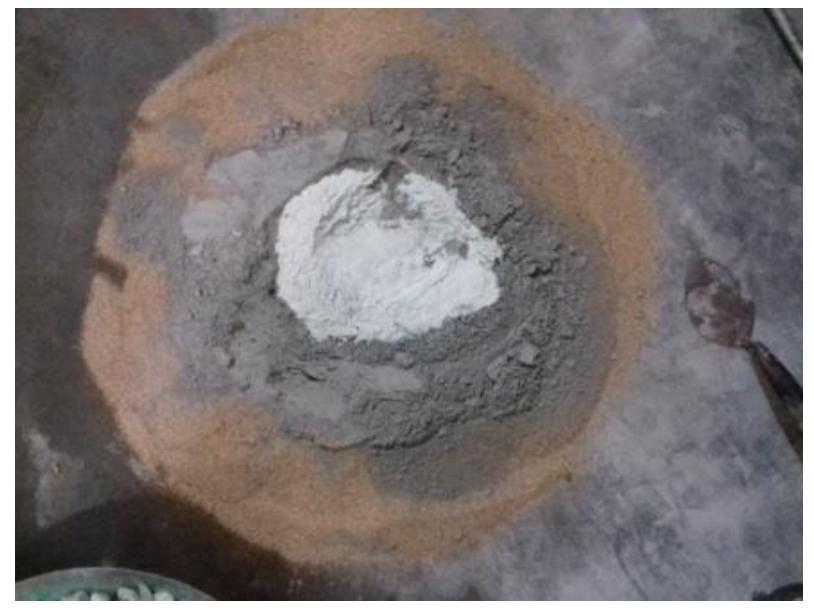

Figure 10. Casting of concrete cylinder

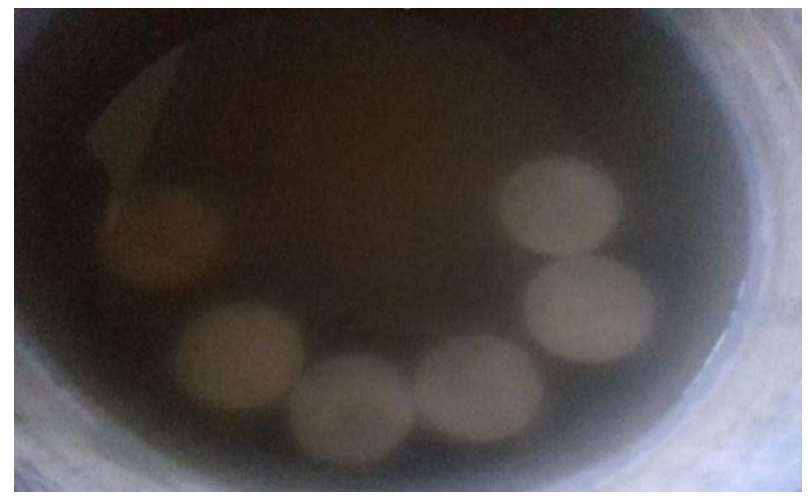

Figure 11. Concrete cylinder under water for curing

\subsection{Compressive and Split Tensile Strength Test}

Compression Testing Machine (CTM) of capacity 2000 $\mathrm{KN}$ was used for both compressive strength test according to ASTM C39-C39M-17 [10] and split tensile strength test according to ASTM C496-C496M-11 [11] of concrete cylinder as shown in Fig. 12 and Fig. 13. Load values were measured from the load cell of CTM.

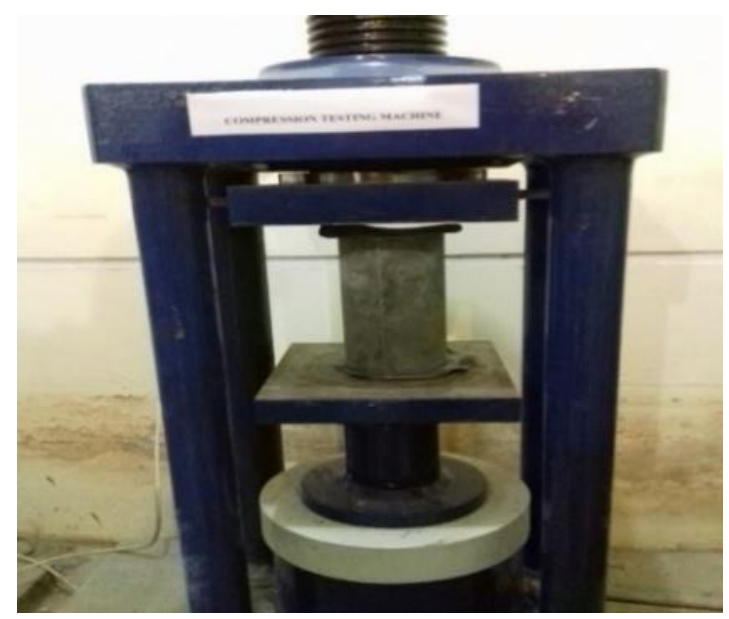

Figure 12. Compressive strength test of concrete cylinder

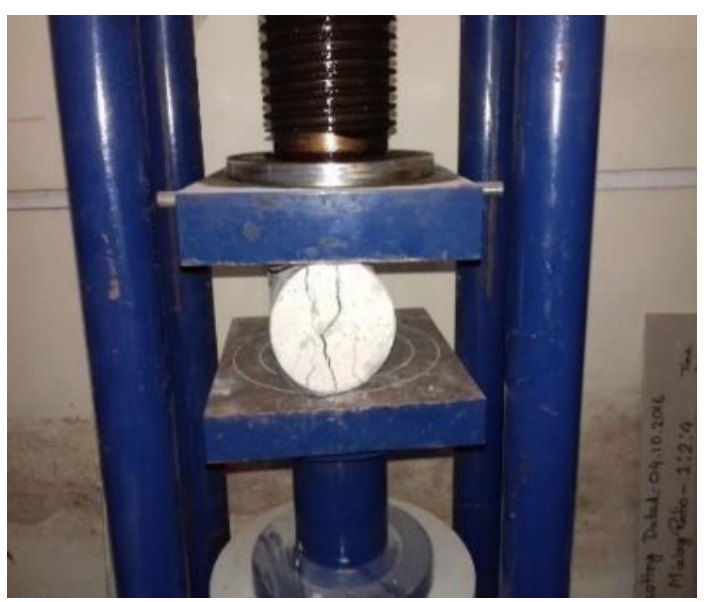

Figure 13. Split tensile strength test of concrete cylinder 


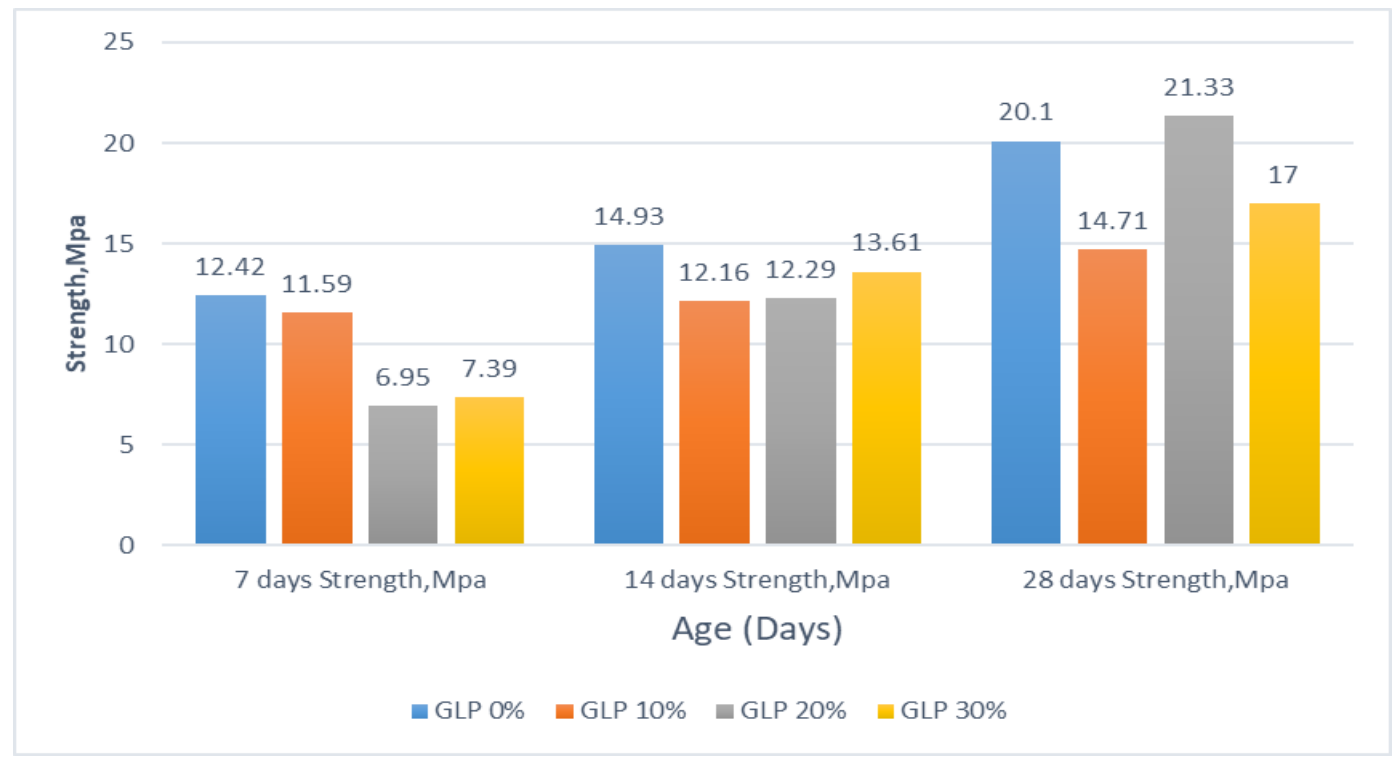

Figure 14. Comparison of compressive strength of concrete with different percentages of waste glass powder

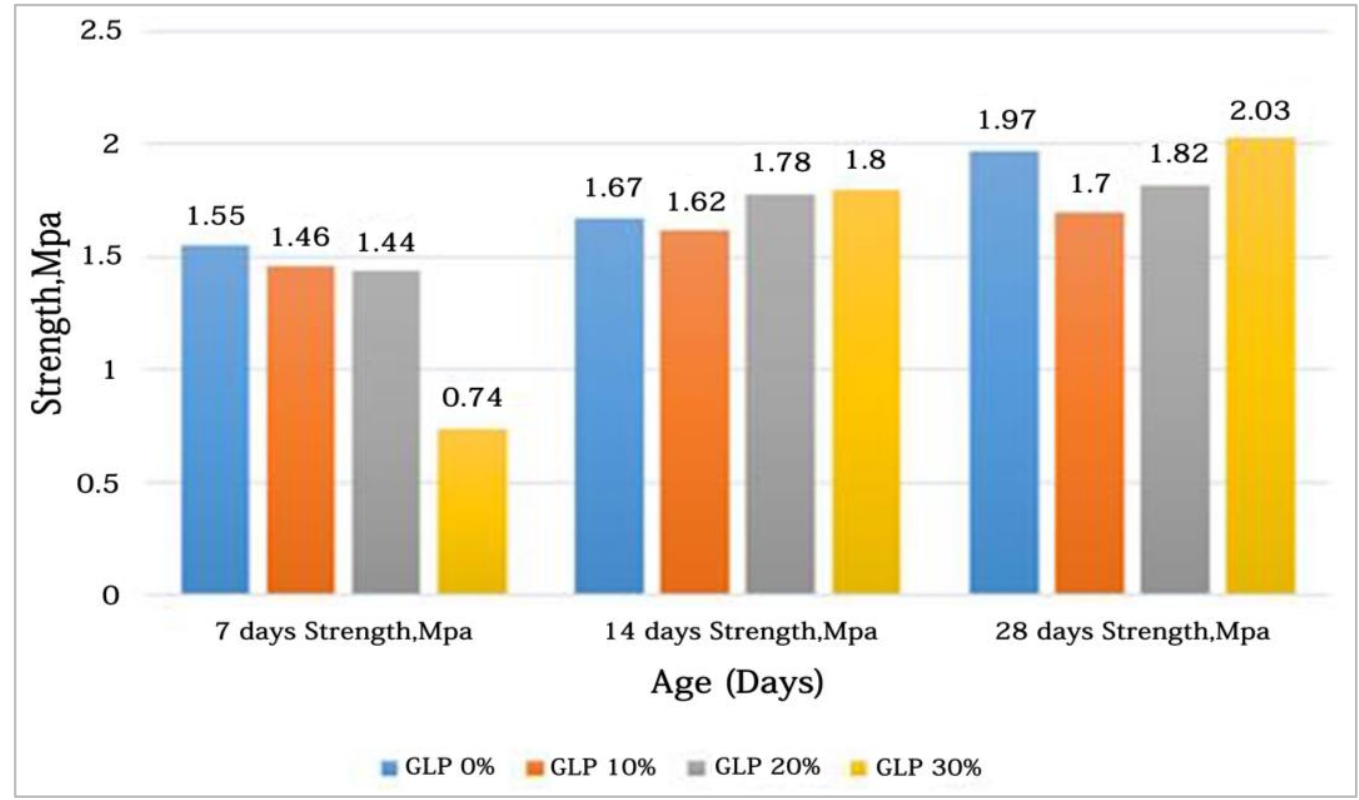

Figure 15. Comparison of split tensile strength of concrete with different percentages of waste glass powder

\section{Result and Discussion}

\subsection{Compressive Strength}

Fig. 14 is showing the comparison of compressive strength of concrete with different percentages of waste glass powder (GLP). Using $10 \%$ of GLP, the compressive strength at 7 days was nearly about of plain concrete but at 14 days and 28 days, the strengths were not much increased and were remained almost stagnant. Using $20 \%$ of GLP, the compressive strength at 7 days and 14 days were much lower than of plain concrete but at 28 days, the strengths was increased marginally and the compressive strength was more than that of plain concrete. Using $30 \%$ of GLP, the compressive strength at 7 days was much lower than of plain concrete but at 14 days, the strength was nearly about of plain concrete and at 28 days, the strength was $15 \%$ lower than plain concrete.

\subsection{Split Tensile Strength}

Fig. 15 is showing the comparison of split tensile strength of concrete with different percentages of waste GLP. Using $10 \%$ of GLP, the splitting tensile strength at 7 days and 14 days were nearly about of plain concrete but at 28 days, the splitting tensile strength was slightly lower than that of plain concrete. Using $20 \%$ of GLP, split tensile strength at 7 days was slightly lower than that of plain concrete but at 14 days, the strength was increased marginally and the split tensile strength was more than 
that of plain concrete. At 28 days, the split tensile strength was slightly lower than that of plain concrete. Using $30 \%$ of GLP, split tensile strength at 7 days was much lower than of plain concrete but at 14 days and 28 days, the strength was significantly increased and the strengths were more than plain concrete.

\section{Conclusions}

\section{The following conclusions were drawn from the above} investigation:

- Compared to plain concrete, the concrete with cement replaced by glass powder has shown better result for compressive strength when the percentages of glass powder was 20, but has shown improved result for split tensile strength for $30 \%$ glass powder. By changing or modifying the various parameters, it is possible to improve the performance of these materials, which plays an important role for eco-friendly construction.

- The addition of recycled green building materials such as glass powder can increase the slump of concrete, but an excessive addition may result in surplus mixing water that could result in slight segregation that can reduce the overall strengths.

- Furthermore, these concrete with glass powder utilize the locally available materials for producing the binding material. So it can be considered as a sustainable material for green construction.

- In general, considering the similar performance with replaced material glass addition can reduce significant cost of cement production and $\mathrm{CO}_{2}$ emission and save the environment by reducing greenhouse gas and particulate production.

\section{Acknowledgements}

The authors would like to acknowledge Department of Civil Engineering, Port City International University,
Chittagong, Bangladesh for giving the opportunity for using the Engineering Materials Laboratory facilities for the experimental works.

\section{REFERENCES}

[1] Cattaneo, JUS. Glass recycling: market outlook, In Resource Conservation Challenge (RCC) 2008 Workshop, 2008, Arlington, Va, USA.

[2] Nasser Almesfer, Jason Ingham. Effect of Waste Glass on the Properties of Concrete, Journal of Materials in Civil Engineering, Vol.26, Issue 11, 2014.

[3] M. H. Rahman, A. A. Shames, G. M. S. Islam. POTENTIAL OF RECYCLED GLASS AS CEMENTITIOUS MATERIAL IN CONCRETE, 2nd International Conference on Advances in Civil Engineering 2014 (ICACE-2014), CUET, 2014.

[4] Dhanaraj Mohan Patil, Dr. Keshav K. Sangle. Experimental investigation of waste glass powder as partial replacement of cement in concrete, International Journal of Advanced Technology in Civil Engineering, ISSN: 2231-5721, Volume-2, Issue-1, 2013.

[5] ASTMC 188-16 Standard Test Method for Density of Hydraulic Cement.

[6] ASTMC 127-15 Standard Test Method for Density, Relative Density (Specific Gravity), and Absorption of Coarse Aggregate.

[7] ASTM C29-C29M-17 Standard Test Method for Bulk Density ("Unit Weight") and Voids in Aggregate.

[8] ASTMC 128-15 Standard Test Method for Relative Density (Specific Gravity) and Absorption of Fine Aggregate.

[9] ASTMC 778-13 Standard Specifications for Standard Sand.

[10] ASTM C39-C39M-17 Standard Test Method for Compressive Strength of Cylindrical Concrete Specimens.

[11] ASTM C496-C496M-11 Standard Test Method for Splitting Tensile Strength of Cylindrical Concrete Specimens 